\title{
Selection of material resources suppliers based on the ranking of competing alternatives
}

\author{
Anna Minnullina ${ }^{1, *}$, and Inna Nekrasova ${ }^{1}$ \\ ${ }^{1}$ Industrial University of Tyumen, Volodarskogo str., 38, Tyumen, 625000, Russia
}

\begin{abstract}
The article proposes the method for ranking of competing alternatives for selection of the suppliers. The method assumes to take into account such criteria as price, quality, distance to the supplier, terms of payment and conditions for obtaining a material resource in the course of selection of the material resources suppliers. To confirm the effectiveness of the proposed method, a comparative assessment of suppliers' preferences in the road-building company SibAgro LLC was carried out without considering the application of the method and conversely.
\end{abstract}

\section{Introduction}

In modern conditions of economic development, a growing interest in the new ideology of logistics - supply chain management - is observed. Most of the advanced companies come to understand the expediency of establishment of long-term relationships with suppliers and consumers for interfunctional and interorganizational coordination of their work in order to increase the efficiency of their own financial and economic activities. This is primarily due to the implementation of the potential for reduction of costs and losses, increasing the speed of response to order fulfillment and improvement of the end-to-end product quality control. A significant contribution to the development of the theory and practice of procurement management was made by the works of such scientists as B.A. Anikin, I.D. Afanasenko, G.L. Brodetsky, E.I. Zaitsev, V.M. Katochkov, V.C. Lukinsky, A.V. Parfenov, N.G. Pletnev, T.A. Rodkin, V.I. Sergeev, L.A. Sosunov, D. Bowersox, D. Kloss, M. Gillingham and K. Laysons, M. R. Linders, D. Waters, H. Firon, et al [1-8].

However, against the background of the active dissemination of the concept of supply chain management, a significant part of Russian organizations pay the excessive attention to inventory management, building a sales system and other logistics functionaries, while underestimating the need to improve procurement activities, taking into account their contribution to the effectiveness of the organization as a whole.

To date, the most acute procurement management problems in Russian organizations are caused by the following circumstances:

- selection of suppliers mainly on the basis of reduction of the price parameters of material resources;

- strengthening of the requirements for the forms of procurement;

- long period of completion of the order for the supply of resources within the

\footnotetext{
*Corresponding author: minnullinaay@yandex.ru
} 
organization;

- duplication of requests for material resources in case of structural disunity of the organization's units;

- complication of the procurement process in connection with the inclusion of the increasing number of links in the supply chain.

Similar problems are quite acute for road-building organizations that consume material resources in large quantities for the production of goods, works and services.

\section{Methods}

When selecting a particular supplier from other possible candidates, certain difficulties arise because all suppliers are characterized by a set of criteria, and according to one criterion, the prospective supplier may differ for the better, and according to other criteria for the worse. As a rule, it is possible to evaluate by the set of criteria only those suppliers with whom the enterprise has already established business relations and concluded the contracts. At the same time, it is impossible to evaluate the new supplier. In this case, it is proposed to use a ranking technique for competing alternatives to decide on the choice of suppliers. The proposed ranking method, based on the theory of fuzzy sets, allows one to significantly reduce the subjective influence of a specialist on the decision made, in particular, to exclude the possibility of taking into account the aspects not foreseen in the examination status. Before proceeding to the use of this methodology, it is necessary to determine the set of criteria by which the company's suppliers will be evaluated. When choosing the evaluation criteria, it is necessary to consider the actual problems of the company. In particular, the lack of free cash for the procurement of materials, which forces the company to pay in instalments for the material resources supplied, as well as the related product receipt terms.

Let us consider the criteria that will be taken into account when selecting the suppliers of material values.

1) Price. Considering the proposals made, they are guided by the level of the average price. The most respectful are the prices that are below the average price. If the price offered by the supplier is higher than the average, then this supplier is rated the lowest.

2) Quality. Usually, all the products of the manufacturers are accompanied by a quality certificate, in which the conformity of the production with GOST and TU is guaranteed. However, some materials must undergo chemical analysis in a special laboratory. The rights granted to the laboratories enable it to return the materials that have not passed quality control to the supplier based on the expertise. In addition, firms may act on the market for reselling goods with fake certificates. The quality of such goods may not meet the requirements.

3) Distance to the supplier. This criterion has a great influence on the formation of the factory overhead costs. Other things being equal, the nearest supplier will be chosen, in other situations the distance factor will also play an important role.

4) Payment terms. The most beneficial for the enterprise would be the payment upon delivery of the products with the provision of credit. However, none of the suppliers offer such conditions due to the instability of the contractual relationship, the lack of confidence in the buyer.

5) Product receipt terms. The current position in the market is such that many suppliers do not trust the guarantees of customers' solvency and ship the products only after receipt of money to their current account, and in case of barter transactions - after receipt of the barterable goods. In this case, the delivery time will depend on the efficiency of the bank. If long-term trusting relationships are established between the supplier and the company, then the product can be received upon delivery of a payment order. 
When using these criteria, it is required to check them for the absence of overlaps, i.e. each of the parameters should not duplicate, in whole or in part, the content of the other criteria. This can be achieved by pairwise comparison of all criteria. If the substantive part of one criterion at least partially reproduces another, then such a criterion should be excluded from the list. The search for the most favorable delivery terms must always be consistent with the delivery of products that are optimal in terms of time and cost. To some extent, this condition takes into account the distance criterion. When choosing a means of transport, they are guided by the speed of delivery, the cost of delivery, the possibility of cargo safety, weight, dimensions, volume of the transported cargo.

The importance of each criterion is determined by the average assessment by a group of specialists, which may include the specialists from the material and technical department, the specialists from the planning and production department, and the chief engineer. Thus, the average score on a 10-point scale gives more objective results of calculations on the choice of the optimal supplier.

Based on the results of assessment of the importance of each criterion, the averaged weight (1) can be calculated as follows:

$$
\mathrm{K}_{\mathrm{i}}=\frac{\sum_{\mathrm{i}=1}^{\mathrm{n}} \mathrm{k}_{\mathrm{j}}}{\mathrm{n}}
$$

$K_{i}$ - is the averaged weight of the $i$-criterion, $i=\overline{1, n}$;

$\mathrm{k}_{\mathrm{j}}$ - the weight of the $\mathrm{i}$-criterion, defined by the $\mathrm{j}$-expert $\mathrm{j}=\overline{1, \mathrm{~m}}$.

Then the pairwise comparison of the criteria in the form of a semi-matrix is performed $\mathrm{F}=\mathrm{W}_{\mathrm{il}}$, where $\mathrm{i}=\overline{1, \mathrm{n}}, \mathrm{l}=\overline{1, \mathrm{n}}$.

According to the completed semi-matrix for the assessment of the importance of each criterion, the most common criteria are determined. A list of the significance of these criteria is compiled. In this case, it is likely that some criteria will be equivalent. In accordance with the compiled list of ordered selection criteria for the suppliers, the suppliers are evaluated directly on a similar 10-point scale. Taking into account the assessment coefficient of importance of the criteria, the choice of the most preferred supplier of material resources is carried out (2).

$$
\mathrm{P}=\sum_{\mathrm{i}=1}^{\mathrm{n}} \mathrm{p}_{\mathrm{di}} \times \mathrm{K}_{\mathrm{i}} \rightarrow \max
$$

\section{Results}

In order to test the proposed methodology, a selection of material resource suppliers for the road-building company "SibAgro" OOO, which carries out its commercial activities in the Tyumen Region, was performed. To date, the priority suppliers of material resources in "SibAgro" OOO are: "Uralasbest" ZAO, "LUKOIL-Permnefteorgsintez" OOO and "STIM" SP. Let the lead specialist of the logistics department select the best supplier. At the first stage, the importance of each criterion for the selection of suppliers for SibAgro OOO is assessed, the results of which are presented in Table 1.

\begin{tabular}{|c|c|c|c|c|c|c|c|}
\hline \multirow[t]{2}{*}{ Criteria } & \multicolumn{6}{|c|}{ Experts } & \multirow{2}{*}{$\begin{array}{c}\text { Criterion averaged } \\
\text { weight }\end{array}$} \\
\hline & 1 & 2 & 3 & 4 & 5 & 6 & \\
\hline Distance & 7 & 5 & 8 & 9 & 8 & 7 & 7 \\
\hline Price & 10 & 9 & 10 & 9 & 9 & 10 & 10 \\
\hline Quality & 1 & 5 & 3 & 4 & 4 & 3 & 3 \\
\hline Payment terms & 5 & 6 & 4 & 5 & 5 & 5 & 5 \\
\hline $\begin{array}{l}\text { Product receipt } \\
\text { terms }\end{array}$ & 8 & 9 & 8 & 10 & 9 & 9 & 9 \\
\hline
\end{tabular}

Table 1. The importance of each criterion. 
The available data on the material resources suppliers (crushed stone, bitumen and road paint) are grouped in Table 2.

Table 2. Characteristics of the suppliers of crushed stone, bitumen and road paint for "SibAgro" OOO.

\begin{tabular}{|c|c|c|c|c|c|}
\hline \multirow[t]{2}{*}{ Suppliers } & \multicolumn{5}{|c|}{ Criteria for selection of the supplier } \\
\hline & $\begin{array}{l}\text { Distance, } \\
\mathrm{km}\end{array}$ & $\begin{array}{l}\text { Price per } \\
\text { unit, } \\
\text { Th.rub. }\end{array}$ & Quality & $\begin{array}{c}\text { Payment } \\
\text { terms }\end{array}$ & $\begin{array}{c}\text { Product } \\
\text { receipt terms }\end{array}$ \\
\hline \multicolumn{6}{|l|}{ Crushed stone suppliers } \\
\hline 1. "Sigma+" OOO & 42 & 373.22 & \multirow{3}{*}{$\begin{array}{l}\text { Complies } \\
\text { with } \\
\text { GOST }\end{array}$} & $\begin{array}{l}\text { Full } \\
\text { prepayment }\end{array}$ & $\begin{array}{l}\text { Shipment at } \\
\text { own } \\
\text { expense, } \\
\text { shipment by } \\
\text { the supplier } \\
\text { after } \\
\text { payment }\end{array}$ \\
\hline 2. "Izvestnyak" ZAO & 216 & 384.51 & & $\begin{array}{l}\text { Transfer to a } \\
\text { bank account } \\
\text { within } 1 \text { day } \\
\text { after billing } \\
\text { for } \\
\text { prepayment }\end{array}$ & \multirow[t]{2}{*}{$\begin{array}{l}\text { Shipment } \\
\text { after receipt } \\
\text { of money to } \\
\text { the current } \\
\text { account }\end{array}$} \\
\hline 3. "Uralasbest" ZAO & 295 & 381 & & $\begin{array}{l}\text { Payment by } \\
\text { installments }\end{array}$ & \\
\hline \multicolumn{6}{|l|}{ Viscous bitumen suppliers } \\
\hline 1. "Sibneft" OAO & 618 & 2797 & \multirow{3}{*}{$\begin{array}{l}\text { Complies } \\
\text { with } \\
\text { GOST }\end{array}$} & \multirow{3}{*}{$\begin{array}{l}\text { Transfer to a } \\
\text { bank account } \\
\text { within } 3 \text { days } \\
\text { after billing } \\
\text { for } \\
\text { prepayment }\end{array}$} & \multirow{3}{*}{$\begin{array}{l}\text { Shipment } \\
\text { after receipt } \\
\text { of money to } \\
\text { the current } \\
\text { account }\end{array}$} \\
\hline $\begin{array}{l}\text { 2. "LUKOIL- } \\
\text { Permnefteorgsintez" } \\
\text { OOO }\end{array}$ & 688 & 2418 & & & \\
\hline 3. "Ufaorgneft" OAO & 876 & 2460 & & & \\
\hline \multicolumn{6}{|l|}{ Road paint suppliers } \\
\hline 1. "TAU-S" OOO & 521 & 55.76 & \multirow[t]{3}{*}{$\begin{array}{l}\text { Complies } \\
\text { with } \\
\text { GOST }\end{array}$} & \multirow[t]{2}{*}{$\begin{array}{l}\text { Full } \\
\text { prepayment }\end{array}$} & $\begin{array}{l}\text { Shipment } \\
\text { after } \\
\text { presentation } \\
\text { of a } \\
\text { payment } \\
\text { order } \\
\text { certified by } \\
\text { the bank } \\
\end{array}$ \\
\hline 2. "Farba-Smol" ZAO SP & 521 & 65.80 & & & \multirow{2}{*}{$\begin{array}{l}\text { Shipment } \\
\text { after receipt } \\
\text { of money to } \\
\text { the current } \\
\text { account }\end{array}$} \\
\hline 3. "STIM" SP & 937 & 58.70 & & $\begin{array}{l}\text { Transfer to a } \\
\text { bank account } \\
\text { within } 3 \text { days } \\
\text { after billing } \\
\text { for } \\
\text { prepayment }\end{array}$ & \\
\hline
\end{tabular}

Then, the above criteria are entered in the table «Matrix of criteria for the supply of crushed stone, viscous bitumen and road paint» (Table 3 ).

At the same time, the number of the most important criterion is entered in the corresponding cell of the compared criteria. For convenience, let us denote each criteria by a specific letter of the alphabet:

1) distance - A;

2) price $-\mathrm{B}$; 
3) quality - C;

4) payment terms - D;

5) product receipt terms - E.

Table 3. Matrix of criteria for the supply of crushed stone, viscous bitumen and road paint.

\begin{tabular}{|c|c|c|c|c|c|c|c|c|}
\hline Criteria & A & B & C & D & E & Frequency & $\%$ & Rank \\
\hline A & & B & A & A & E & 2 & 20 & 3 \\
\hline B & & & B & B & B & 4 & 40 & 1 \\
\hline C & & & & D & E & 0 & 0 & 5 \\
\hline D & & & & & E & 1 & 10 & 4 \\
\hline E & & & & & & 3 & 30 & 2 \\
\hline Total & & & & & & 10 & 100 & - \\
\hline
\end{tabular}

After evaluation by the method of semi-matrix, a list of ordered criteria is revealed. In accordance with the established list of criteria, the suppliers are assessed on a 10-point scale. The results of the evaluation of suppliers are presented in table 4.

Table 4. The assessment of material resources suppliers according to specified criteria.

\begin{tabular}{|l|c|c|c|c|c|c|}
\hline \multirow{2}{*}{ Suppliers } & \multicolumn{7}{c|}{ Criteria by ranking } \\
\cline { 2 - 7 } & $\mathrm{A}$ & $\mathrm{B}$ & $\mathrm{C}$ & $\mathrm{D}$ & $\mathrm{E}$ & Total \\
\hline \multicolumn{7}{|c|}{ Crushed stone suppliers } \\
\hline 1. "Sigma+" OOO & 9 & 7 & 8 & 1 & 8 & 33 \\
\hline 2. "Izvestnyak" ZAO & 7 & 5 & 8 & 5 & 5 & 30 \\
\hline 3. "Uralasbest" ZAO & 6 & 6 & 8 & 9 & 5 & 34 \\
\hline \multicolumn{7}{|c|}{ Viscous bitumen suppliers } \\
\hline 1. "Sibneft" OAO & 4 & 4 & 8 & 4 & 5 & 25 \\
\hline $\begin{array}{l}\text { 2. "LUKOIL- } \\
\text { Permnefteorgsintez" }\end{array}$ & 3 & 6 & 8 & 4 & 5 & 26 \\
OOO & 2 & 5 & 8 & 4 & 5 & 24 \\
\hline 3. "Ufaorgneft" OAO & \multicolumn{7}{|c|}{ Road paint suppliers } & & & \\
\hline & 5 & 9 & 8 & 1 & 3 & 26 \\
\hline 1. "TAU-S" OOO & 5 & 7 & 8 & 1 & 4 & 25 \\
\hline 2. "Farba-Smol" ZAO SP & 5 & 8 & 8 & 4 & 5 & 25 \\
\hline 3. "STIM" SP & 1 & 8 & & & \\
\hline
\end{tabular}

According to table 4, the most preferred supplier is selected. In this case, the best suppliers of crushed stone, viscous bitumen and road paint are "Uralasbest" ZAO, "LUKOIL-Permnefteorgsintez" OOO, "TAU-S" OOO, respectively. However, this assessment system does not take into account the significance of each of the criteria. If we add a ten-point system for assessing the significance of each of the criteria, then we get a different, more accurate picture of the assessment of the material resources suppliers for SibAgro OOO (Table 5).

Table 5. Supplier assessment, considering the importance of criteria.

\begin{tabular}{|l|c|c|c|c|c|c|}
\hline & \multicolumn{7}{|c|}{ Criterion } \\
\cline { 2 - 7 } & $\mathrm{A}$ & $\mathrm{B}$ & $\mathrm{C}$ & $\mathrm{D}$ & $\mathrm{E}$ & Total \\
\hline $\begin{array}{c}\text { The importance of the } \\
\text { criterion }\end{array}$ & 7 & 10 & 3 & 5 & 9 & 7 \\
\hline \multicolumn{7}{|c|}{ Crushed stone suppliers } \\
\hline 1. "Sigma+" OOO & 63 & 70 & 24 & 5 & 72 & 234 \\
\hline 2. "Izvestnyak" ZAO & 49 & 50 & 24 & 25 & 45 & 193 \\
\hline 3. "Uralasbest" ZAO & 42 & 60 & 24 & 45 & 45 & 216 \\
\hline \multicolumn{8}{|c|}{ Viscous bitumen suppliers } \\
\hline 1. "Sibneft" OAO & 28 & 40 & 24 & 20 & 45 & 157 \\
\hline
\end{tabular}




\begin{tabular}{|l|c|c|c|c|c|c|}
\hline $\begin{array}{l}\text { 2. "LUKOIL- } \\
\text { Permnefteorgsintez" OOO }\end{array}$ & 21 & 60 & 24 & 20 & 45 & 170 \\
\hline 3. "Ufaorgneft" OAO & 14 & 50 & 24 & 20 & 45 & 153 \\
\hline \multicolumn{7}{|c|}{ Road paint suppliers } \\
\hline 1. "TAU-S" OOO & 35 & 90 & 24 & 5 & 27 & 181 \\
\hline 2. "Farba-Smol" ZAO SP & 35 & 70 & 24 & 5 & 45 & 179 \\
\hline 3. "STIM" SP & 7 & 80 & 24 & 20 & 45 & 176 \\
\hline
\end{tabular}

After the introduction of the evaluation coefficient of the importance of the criteria, a change occurs in the priority of choosing a potential supplier. The best suppliers of crushed stone, viscous bitumen and road paint, based on table 5, are "Sigma +" OOO, "LUKOILPermnefteorgsintez" OOO and "TAU-S" OOO. Thus, the objective assessment of the suppliers is presented in the last table.

\section{Conclusions}

The obtained data on the recommended evaluation of the choice of material resources suppliers is quite at variance with the data obtained in the analysis of suppliers, with whom close business relations are maintained today. This suggests that the currently used method of determination of the best material resources supplier at "SibAgro" OOO is not effective. In this case, it is recommended to review the relations with the suppliers "Uralasbest" ZAO and "STIM" SP, with which "SibAgro" OOO has recently been working, and to conduct a comparative assessment of the companies with "Sigma +" OOO and "TAU-S" OOO.

The introduction of the proposed methodology for evaluation of the suppliers is possible with the help of a computerized program, which will facilitate the work of the logistics department, speed up the selection process and reduce the costs. It is recommended to develop this automated calculation algorithm not on the basis of special software, which often requires a powerful operating system as a base, but on the basis of a traditional Microsoft Excel spreadsheet. The advantage of this organization is a reduction in the cost of introduction of this product, training of the staff in the field of proper use of the program, as well as the use of the great potential of Microsoft Excel.

\section{References}

1. Yu.A. Borodina, O.M. Syardova, The strategy of sustainable develop 18, 56 (2013)

2. A.V. Sysolyatin, Electronic scientific journal 113, 1-7 (2015)

3. A. Kopytova, Procedia Engineering 165, 1132 (2016)

4. A.Yu. Minnullina, Economics and Entrepreneurship 5-2, 734(2014)

5. E. Vozniak, A. Burgundosova, A. Kopytova, MATEC Web of Conferences 239, 01016 (2018) DOI: 10.1051/matecconf/201823901016

6. V. Lez'Er, M. Gusarova, A. Kopytova, MATEC Web of Conferences 170, 01066 (2018) DOI: 10.1051/matecconf/201817001066

7. Y.V. Truntsevsky, I.I. Lukiny, A.V. Sumachev, A.V. Kopytova, MATEC Web of Conferences 170, 01067 (2018) DOI: 10.1051/matecconf/201817001067

8. D. Izvin, V. Lez'er, A. Kopytova, MATEC Web of Conferences 170, 01065 (2018) DOI: $10.1051 /$ matecconf/201817001065 